Article

\title{
Transnational Practices and Migrant Capital: The Case of Filipino Women in Iceland
}

\author{
Unnur Dís Skaptadóttir \\ Department of Anthropology, University of Iceland, 101 Reykjavik, Iceland; E-Mail: unnurd@hi.is
}

Submitted: 29 June 2019 | Accepted: 1 October 2019 | Published: 19 December 2019

\begin{abstract}
Filipinos have been moving to Iceland in increasing numbers since the 1990s, primarily for employment opportunities and to reunite with relatives. They are the third largest group of immigrants in Iceland and the largest group from Asia. The majority of them work in low-income jobs in the service and production sectors where they do not utilize their education. Many arrived with the help of relatives already living in Iceland. Based on multi-sited ethnographic research, this article examines the diverse mobilization of migrant capital in Iceland and in the Philippines. The analysis draws on Bourdieu's concepts of capital and transnational theories to highlight how Filipinos draw on formal and informal resources in Iceland and their transnational social field in mobilizing their capital. Their extended kin groups in Iceland and networks back in the Philippines are important in building migrant capital in Iceland and in the Philippines. The study shows that this mobilization is not only affected by structural factors in Iceland, such as racialization, but also by economic position and cultural capital in the Philippines.
\end{abstract}

\section{Keywords}

Bourdieu; Filipinos; Iceland; migrant capital; social capital; transnationalism

\section{Issue}

This article is part of the issue "Social Inclusion beyond Borders: Utilization of Migrant Capital in Transnational and Diaspora Communities" edited by Sanna Saksela-Bergholm (University of Helsinki, Finland), Mari Toivanen (University of Helsinki, Finland) and Östen Wahlbeck (University of Helsinki, Finland)

(C) 2019 by the author; licensee Cogitatio (Lisbon, Portugal). This article is licensed under a Creative Commons Attribution 4.0 International License (CC BY).

\section{Introduction}

Filipinos are the third largest migrant group in Iceland and the largest from Asia. The group consists of twice as many women as men. This migration began in the early 1990s, with a small number of women arriving to be with their Icelandic spouses. Employment has been an important motivation for the continued migration of people from the Philippines to Iceland. An important goal for most of them is to improve their and their children's lives, as well as to help provide for family members living in the Philippines. Despite their high levels of education, Filipinos, for the most part, work in low-income jobs, and they can only apply their education or cultural capital to a limited extent. In Iceland, Filipino women are often portrayed, along with other Asian women, as a vulnerable group and as potential victims of marriage migration (Skaptadóttir, 2015). Their differences and agency in mobilizing capital for their own projects is often made invisible in this discourse.

The vulnerable position of migrants in the labour market and in society in general is often discussed in relation to the loss of social and cultural capital that they experience when moving to another country. At the same time, researchers have increasingly focused on migrants' social networks and how they mobilize their capitals in new social and economic contexts. Research on transnationalism has shed light on how migrants continue to maintain important links to their countries of origin and on how these connections affect their experiences and opportunities in the host countries. Bourdieu's conception of social, economic and cultural capital is a useful tool to examine how migrants are both agents in their migration trajectories and affected by larger social structures that limit their possibilities (Kelly \& Lusis, 2006). 
This article explores Filipino women's experiences and positions in relation to their migration to Iceland. It draws on Bourdieu's concepts of social and cultural capital, on the one hand, and on a transnational perspective to highlight their different migration trajectories, on the other. Bourdieu's approach to social capital sheds light on individual agency and networks when people mobilize their resources to build capital. In addition, his theories can also serve as a tool to understand the maintenance of inequality and how structural relations may affect an individual's possibilities to change position (Bourdieu, 1986). Based on a study that applied ethnographic methods over a longer time in both Iceland and in the Philippines, the article examines how local and transnational social networks are, in many instances, imperative in shaping migrant capital. Focusing only on their lives in Iceland would only portray one side of the picture.

Describing the migration trajectories of five individual women, the article examines Filipino women's divergent positions in relation to their ability to accumulate or mobilize resources to increase their economic, social and cultural capital locally and in a transnational context. To shed light on these processes, it is essential to consider the motivations of different individuals and the societal contexts in which they act. The article explores how the women apply various resources, such as their education or networks in Iceland, to improve their positions. It also depicts how remittances and maintaining transnational relations play a role in the construction of migrants' capital and how people sometimes improve their position and class status in their countries of origin. Transnational practices and utilization of migrant capital additionally take place in the context of a Filipino national political economy and ideology that encourages people to leave in order to care for those left behind (Barber, 2008, 2010). The context of racialization and class position in Iceland when building of capital must also be accounted for (Loftsdóttir, 2017).

The article shows the importance of combining these different aspects when analysing migrant capital. The article begins with a discussion of migrant capital and of how Bourdieu's theories of social capital are useful in increasing the understanding of the processes of capital building in the host society. The analysis of migrant capital also implies adding a transnational perspective to highlight how migrants' positions in and continued ties with the sending society may affect their ability to build capital. After a brief description of the study, the results are presented beginning with a short background on Filipinos in Iceland. Then, the different migration trajectories of the five women chosen for this analysis are examined.

\section{Social Capital and Transnational Relations}

Many scholars have examined the social networks of migrant populations and applied diverse theories of social capital when examining the experiences and positions of migrants. Recently, they have increasingly studied migrant capital, or how and to what extent migrants utilize resources available to them to maintain and create their capital through transnational and local networks (Erel, 2010, 2015; Paul, 2013; Ryan, Erel, \& D’Angelo, 2015). According to Bourdieu, people's positions in society are determined by the volume of their social, cultural and economic capital. Bourdieu wrote most extensively about cultural capital, which refers to status in society that correlates with an individual's competences acquired when growing up. These can, for example, be reflected in taste or the way people speak or institutionalized in educational degrees (Bourdieu \& Wacquant, 1992). Economic capital indicates economic possessions. Social capital refers to the ability to activate social networks to build and reinforce economic and cultural capital (Bourdieu \& Wacquant, 1992). All three kinds of capital are interconnected, so that persons born into a particular social field can increase their capital, for example, by converting economic capital into cultural capital by investing in education or art (Bourdieu, 1986). Differing amounts of cultural, economic and social capital reveal inequalities in society and how they are maintained, as reflected in Bourdieu's conceptions of social class and distinction (Bourdieu \& Wacquant, 1992).

International migration is motivated by many factors. Working abroad in order to improve economic position is an important one, although it is often combined with other motivations (Paul, 2015). Migration research has highlighted how labour migrants draw on their local and transnational networks to find work abroad (Alberti, 2014). Many contemporary migrants are stuck in lowincome and low-status temporary jobs (Anderson, 2010; Standing, 2011). They are commonly in specific niches of the labour market, independent of their former work experience and education (McDowell, 2008; Schrover, der Leun, \& Quispel, 2007). Migrants often have difficulties in transferring their cultural capital when moving to a new country (Erel \& Ryan, 2019). Paying attention to the everyday practises and individual strategies of migrants when improving their positions is important but should not lead to disregarding structural factors that limit their choices (Alberti, 2014). Different possibilities for travel and mobilizing their resources reflect the contemporary world of global inequalities registered in the flows of capital and people within the global political economy, where certain regions have become migrant-sending and others migrant-receiving (Barber, 2008; Mahler \& Pessar, 2006). Racialization and practises of discrimination are commonly limiting factors in the mobilization of cultural capital for migrants (Erel \& Ryan, 2019).

Despite losses through the migration process, people often attempt to confirm their capitals and generate new ones, for example, by engaging in migrant networks. Such networks can be valuable for migrants in order to access jobs, housing and information. As pointed out by Erel and Ryan (2019), migrants do not simply begin 
to accumulate cultural, social and economic resources, since gains, losses and reorientations of capitals are connected across different social fields and the wider context of the society of residence. Moreover, migrant networks are not homogenous, and they may reflect hierarchical social positions where gender, class and other positions intersect. It cannot, therefore, be assumed that a migrant will necessarily be able to seek help or support from ethnic networks (Anthias, 2007; Erel, 2010).

Studies applying transnational perspectives have depicted how migrants continue to participate in the daily life of their countries of origin through the internet or travel when moving to another country and how they are embedded in multi-layered transnational social fields. Their identities and positions continue to be formed by participation in two nation states (Glick Schiller, 2010; Vertovec, 2006). The ability to care for those left behind, be it children, parents or others, is often an important reason for working abroad. Sending remittances can, in addition, boost people's social status in the country of origin. Remittances, either in cash or in kind, are not only between individuals or close family but can also take a collective form, raised by a group of people to support a particular group or community in the country of origin (Rahman \& Lian, 2012).

Much has been written about the various aspects of Filipino migration, both about transnational relations and social networks, for example, on such themes as the global care chain and left-behind children and of migration of nurses and other health-sector workers. These studies have provided insight into the importance of the remittances and transnational family lives of many Filipinos (Madianou \& Miller, 2012; Mahler \& Pessar, 2006; Parreñas, 2005; Spitzer, Neufeld, Harrison, Hughes, \& Stewart, 2003). Kelly and Lusis (2006) have shown that, among the Filipinos in Toronto, social capital is commonly an asset they bring with them from the Philippines. Conceptions of responsibilities and expressions of love and care are all important in transnational family ties and are often important motivations for sending remittances (Parreñas, 2005). The remittances sent to family must also be considered in the context of the limited welfare services in the Philippines (Barber, 2008). Since the 1970s, the government of the Philippines has emphasized the outmigration of workers as an economic strategy for gaining remittances from those working abroad. The government has encouraged emigration and the portrayal of Filipinos as good and loyal workers who can adjust to new cultures easily (Barber, 2008; Paul, 2015).

\section{The Study}

The discussion in this article is based on a longitudinal, multi-sited ethnographic study among Filipinos living in Iceland beginning in 2009. As an ethnographic study, participant observations and informal conversations on various occasions were important during the data collection. During this extended period, I conducted semi- structured interviews with 65 persons, some repeatedly, and three focus groups and recorded numerous participant observations and informal conversations at various large and small events. The interviews were conducted in English or Icelandic, except for a few that were partly conducted in Cebuano or Tagalog and translated to English.

The study took place in Reykjavík, the capital of Iceland, in the surrounding municipalities and in three small towns in other parts of Iceland. It also included a research trip in 2011 and another in 2014 to the Philippines for about six weeks each, with participant observations and interviews taking place primarily in the Visayan area, but also in Manila. In the Philippines, I stayed with participants' families and travelled with Filipino women who assisted me in the research. The first 30 participants were selected based on their age, gender and how long they had been living in Iceland, using a list provided by Statistics Iceland. After the initial stage, participants were recruited using the snowball method. In the Philippines, interviews and informal conversations were conducted mostly with the family members and friends of the participants in Iceland. Others were taken with nursing students about their ideas on emigration.

More women than men participated in this research, and women were more willing than men to be interviewed. In this article, I focus on five women's stories to highlight the different ways in which they mobilize their capital. They do not reflect the diverse experiences of all Filipinos in Iceland but were chosen as their stories depict differences in their positions and abilities to mobilize resources to build capital. These women have all been in Iceland for 10 years or more and all speak Icelandic. The names are pseudonyms, and I have attempted to hide their identities in other ways. As one of them may still be recognized, the description of her story was written while consulting with her.

\section{Filipinos in Iceland: The Women's Stories}

The migration of Filipinos to Iceland began in the late 1980 s and early 1990s with women arriving due to marriage with Icelandic spouses. They have since been one of the largest migrant groups in Iceland and are currently the third largest group of immigrants after Poles and Lithuanians. Women from the Philippines have always been more numerous than men, and in January of 2018, there were 1,245 women and 633 men born in the Philippines living in Iceland, a country of 348,450 inhabitants (Statistics Iceland, n.d.). The primary reasons almost all participants gave for their migration to Iceland was to improve their economic situation and to provide for their families back in the Philippines. Being with a family or spouse in Iceland was also commonly mentioned. The majority of the participants had tertiary education before arriving, and some chose their education with working abroad in mind. Secondary and tertiary education is generally conducted in English in the Philippines, and thus, most of the women spoke good 
English upon arriving in Iceland. A small minority have been able to use their education, such as nursing, but the majority work in low-income, low-skilled jobs in various food production and service sectors, mostly with other immigrants (Júlíusdóttir, Skaptadóttir, \& Karlsdóttir, 2013; Skaptadóttir, 2015; Yingst \& Skaptadóttir, 2018).

Although many have improved their economic situations, many participants also talk about not being respected or not getting promotions at work. Because of this, they express a loss of cultural capital and social status. This is in accordance with Kristjánsdóttir and Christiansen's (2019) study, which showed that Filipinos in Iceland, who work as specialists, commonly experience prejudice in their workplaces. They are affected by the racialization of Asian women in Iceland (Skaptadóttir, 2015), and in my study, many talk about incidents where they experienced racism. One woman said that, "it is because of our black hair. It is because people see us only as Filipinos, not as someone who might be interested in films or art." While there are stronger stereotypes about Filipino women in Iceland than about Filipino men, the women have been more prominent in Filipino organizations than the men. They have also played more active roles than men in the promotion of immigrant issues in Iceland, such as being contact persons for the Red Cross or local governments (Skaptadóttir, 2015).

The majority of immigrants from the Philippines, or $86.5 \%$, who have been in Iceland for more than ten years have Icelandic citizenship, indicating long-term settlement plans (Skaptadóttir \& Garðarsdóttir, in press). The majority keep strong ties with the Philippines and are engaged in life there. They send remittances and communicate regularly with their families in the Philippines. Many of them travel there on a regular basis to attend to property, visit their parents and other family, or to take part in important life events. These transnational ties, however, differ based on, for example, age, marital status and class. Very few of the women participating in the study left their children behind when going to Iceland. Most did not have children before arriving in Iceland, and those who did either arrived with them or were soon reunited with them. Thus, their remittances are mostly for their parents and, in some cases, also for siblings, nephews and nieces. Many of them had a parent or other relatives working abroad when they were growing up who sent remittances to their family.

Social networks among the participants living in Iceland consist mostly of people from the same area in the Philippines or of extended kin groups of various sizes. Many received help from these groups when first finding their way in Iceland. The extent to which they can use such networks to build their social capital and improve their position varies. The different ways to mobilize migrant capital play out in various ways in the following narratives from five women who participated in the research. Their individual stories highlight how they have been able to mobilize their capital to different degrees and in different ways both locally and transnationally.

\subsection{Five Women's Migration Trajectories}

\subsubsection{Grace}

Certain women who arrived in Iceland in the 1990s went on to arrange for many people to come to work in Iceland and have mobilized their capital to build a strong migrant network. These women have gained respect and commonly serve as intermediaries between local Filipinos and Icelanders. In a small town where I conducted field research, most of the Filipinos had arrived through chain migration that began with Grace. In this town, both Icelanders and Filipinos would point out how Grace was the most important person to talk with in the village to get information about Filipinos. Grace arrived with the help of her aunt who lives in Reykjavík just after finishing a college degree in business in the Philippines. She began to work in a job her aunt had arranged for her in food production. Soon after arrival, she met her Icelandic husband, and they moved together to the small town where they have lived since. She has been employed in a parttime cleaning job but has not found a way to use her education in relation to her work. She described how she began helping other Filipinos to come to Iceland, such as her sister Joselyn:

First, Joselyn came to help me with taking care of my child when I was working, and then my two cousins came, who I had found a job for in the fish processing, and then one of them went to England, and three more cousins then came here.

The other Filipinos in the town explained how thankful they were for her help, for example, with arranging jobs for them in Iceland, translating letters and going with them to offices and institutions when seeking various services. When asked about their familiarity with local services, many of them replied that they could just ask Grace. They said that they respected her and trusted the information she provided. Grace claimed that they, in fact, knew about these services: "I do not need to tell them, but I can help them, and I like helping them."

Grace and her husband are doing well economically as he is employed as a specialist in a stable office job. They live in a spacious house with a nice view of the ocean. The respect Grace has gained in the town primarily reflects her ability to mobilize her capital locally among Filipinos. Although Grace claimed in an interview that she has no social networks among Icelanders, Icelanders knew her and her central role in the Filipino community, and they claimed that she was more active in local life than most other Filipinos. Moreover, they claimed that her Icelandic was better, whereas most of the other Filipinos communicated mostly in English.

Many of the participants talked about how having social networks made up of extended family and people from their islands in the Philippines was an important reason for their well-being in Iceland. The networks made 
life liveable in the harsh environment, darkness and difficult weather conditions in Iceland, with hard work of long hours. Grace said that:

It is not difficult to live here, especially now. Before, people came here with no family just to work. It can be difficult with no family to help you or to talk with. But now, people are here because their family is here. We, the Filipinos here, help each other, except for the two sisters you met the other day. Only my sister is in contact with them. They are not related to us and they keep to themselves and are not in much contact with other Filipinos here.

\subsubsection{Elsa}

Not having a family network was often discussed in terms of vulnerability and lacking possibilities. Elsa came to Iceland with a friend through an Icelander they had met in the Philippines, who helped them find work cleaning in a hotel. Because her permission to stay in Iceland was dependent on this work, she said that she had to start working the day after arrival. Before coming to Iceland, she knew almost nothing about the country, and she had no connection to people in the Philippines who had relatives in Iceland. When I met her for the first time a few years after her arrival, she kept telling me: "I am all by myself." When I expressed my surprise and mentioned her Filipino and Icelandic friends and her Icelandic husband and daughters, she said that "it is not the same. I am all alone here." Later, she was able to arrange for her aunt to come to work in Iceland. The aunt brought her husband and two daughters.

Her father had worked abroad when Elsa was a child, but Elsa said that it was her maternal aunt's remittances that had been most important for financing her university education in hotel management. Elsa felt indebted to her aunt and wanted to help her move to Iceland. Today, Elsa has mostly Icelandic friends, and although she maintains friendships with a few women from the same region in the Philippines, she does not attend activities with other Filipinos or go to Catholic mass. She speaks Icelandic at home with her daughters and her husband. When she encountered problems in the past in relation to work and relationships, she says that she sought help from her Icelandic friends and did not want Filipinos to know of her problems. She speaks good Icelandic and has been able to use her education working in a hotel, especially after completing a master's degree. She explains, though, that, as an Asian woman, she has had to prove herself at work by doing everything twice as well as Icelanders. Moreover, she claims that she has observed less qualified Icelanders being promoted before her in the hotel where she is currently employed. She says that she feels better in Iceland now because her mother's sister and her family live there. Elsa keeps in touch with her family through social media, sends remittances to her parents and has invested in housing for them in the Philippines, but rarely travels there. She claims that having an Icelandic husband, her light skinned daughters, a nice house and being in good economic standing confirms that she is a successful migrant. She thinks that it is more important for her daughters' futures to know English and Icelandic than her mother tongue. When traveling to the Philippines, it is important for her to show people there that she is doing well and that she can buy things for her family and take them out.

\subsubsection{Anna}

Anna comes from an educated family in the Philippines and belongs to the cultural elite there. Her parents possessed a high amount of cultural, economic and social capital. They were highly educated and both had high positions in their fields of work. Their plan was for Anna to study medicine. She finished a nursing degree and went into medicine. Although she appreciated her parents concern for her future, she quit medicine to pursue a career as a journalist and an editor. About ten years later, she decided to seek a job as a nurse abroad at the request of her mother, who was seriously ill. The reason she chose Iceland as a destination was because some people from the region her father comes from were living in Iceland. They assisted with practicalities and offered Anna a place to stay upon arrival.

As with other nurses arriving from the Philippines, Anna began to work as a nursing assistant, but felt confident that she could do the job. Having already learned another language while living abroad before, Anna attended courses and learned Icelandic fast and was able to get the Icelandic nursing licence relatively quickly. She has been able to connect easily with Icelanders at work, including her managers. She has also been involved with writers' groups and has written for an English language magazine in Iceland. Thus, she has, to a larger extent than other participants, been able to transfer her cultural capital into the Icelandic context. In spite of this, she experienced a loss of social and cultural capital when moving to Iceland, where she says she is commonly perceived as "just a Filipino" or merely "an Asian woman." When promoted into a higher position at work, she found that some of her co-workers did not approve of the promotion because she is a foreigner.

Anna and her siblings, who also live and work as specialists abroad, send remittances to their father, who lives with a few live-in helpers and a relative who has come to the city to attend college. In addition to owning several properties that need to be attended to, they are landowners. Although the estate in the countryside is maintained financially through agriculture, they have responsibilities toward the tenants there. When I travelled with Anna to the countryside, we brought along many boxes of gifts in the spirit of the balikbayan boxes commonly sent from migrants to the Philippines as in-kind remittances to the caretakers and the tenants. Some of 
these gifts were for certain individuals and other for communal use, such as some construction tools.

During her yearly visits to the Philippines, Anna stays in contact with friends and close relatives, and more distant relatives commonly seek assistance and advice from her. She also supports the education of a few children and one college student. She says that she has inherited all these responsibilities from her parents, responsibilities that contribute to the maintenance of her social and cultural capital. Anna has also been able to transfer her cultural capital to the Filipino community in Iceland. She is without a kin group in Iceland, but still belongs to a strong network of Filipinos in Iceland who come from the region of her father. Filipinos from her network are aware of the status of her family.

\subsubsection{Vanessa}

Vanessa comes from a small rural village and her class position stands in contrast to Anna's. She comes from a rather economically deprived family, and similar to some other women in my study, she said that she had been interested in finding a Western man so that she would be able to move from the Philippines. Vanessa had been hoping to meet someone from the United States or Australia, but unlike some of the other participants of the study, she had not initiated any contact on the internet or by letter writing. She met her former husband while working in a nearby city and accepted his proposal to marry in the Philippines shortly after they met. Vanessa said that she had hoped that he was a good man. By marrying him, she anticipated that she would have had the opportunity to work in Iceland and help her family by sending them remittances. However, after arriving in Iceland to be with her husband, he turned out to be abusive and banned her from working outside the home and going to church. Despite this, Vanessa managed to get in touch with Filipinos who came from her island in the Philippines. They helped her escape the situation along with her son and to move to another town. When reflecting back on the decision to marry a man she hardly knew, she claimed that she, in a way, had to make this sacrifice for her family and said that "you have to understand, in the Philippines the family is everything." She later remarried, and she and her new husband helped her sister move to Iceland. She says that she knows only a few Icelanders through her current husband but not people whom she would consider to be friends or would ask for advice or help. She spends her free time mostly with other Filipinos, and her husband has, in a way, been integrated into her Filipino community.

Unlike most of the other participants in my study, Vanessa quit high school and her English is not as fluent as that of the other participants. In Iceland, she has been moving from one low-income job to another, where she has generally worked alone or with other foreigners. Thus, learning Icelandic has taken a long time. She stays in touch with her family back in the Philippines on a daily basis through social media, but seldom visits them. When I visited her family in the Philippines, Vanessa had recently lost her job. Her husband, who has visited the family in the Philippines with her, is very supportive of sending remittances, but he is in a low-paid job as well. Although they did send money at the time, it was more sporadic than they would like. The parents expressed understanding of their limited remittances and said that they were lucky that they had other children abroad who could send them money as well. When I visited them, they lived in a small house with two daughters, a son-in-law and five grandchildren. They proudly showed me pictures of their successful migrant son in America. Vanessa was later able to send more remittances to her parents than before, and she claimed that moving to Iceland had greatly improved her life. She said that she is better off than she would have been if she would have stayed in the Philippines, and she is happy with her husband, who respects her as an equal partner.

\subsubsection{Rosa}

Rosa had recently graduated with a teaching degree when she came to Iceland in the early 1990s. She had been considering writing letters to male pen pals in the United States with the goal of moving there, when her cousin in Iceland offered her a chance to come and work. As with many other foreign women at that time, she started working in a fish processing plant and later moved to a position cleaning in a hospital. She has not considered becoming a teacher in Iceland, but she did, for a short time, have a temporary job supporting immigrant children in a primary school. She married an Icelander after a few years and later arranged for her sister to join her in Iceland. She raises her children in what she refers to as "the Filipino way," including teaching them her mother tongue and respect for elders. Rosa now has a large network of relatives in Iceland, many of whom come from the same small community in the Philippines as her. The two sisters have helped many of these relatives and friends find work in Iceland. Her husband, like Vanessa's husband, is involved in a Filipino network and travels with her regularly to the Philippines. They have, in some cases, housed migrants from her hometown after they first arrived. Rosa sends money back to her elderly parents every month. She has also invested in a beautiful house in the town from which she comes. Although Rosa says that she has experienced racism, such as being told to go home in a public place, she generally feels happy in Iceland. She claims that, although she has had to work hard, she can provide her children with better futures in Iceland than in the Philippines.

A few years ago, Rosa and her sister played central roles in organizing a fiesta in the village they come from in the Philippines. In the months prior to their travel, they were engaged in funding activities such as parties with dinner, dancing and a lottery and selling various things. 
A group of almost 50 persons, including children, then travelled from Iceland to the Philippines to participate in the fiesta. There, the group from Iceland decorated the village with flags and organized a parade. They paid for a wall to be painted in front of the church, for musicians and much more. At the fiesta, there were large gatherings with performances of regional dances. The group from Iceland proudly paid for the visit of a number of priests and a bishop who gave an inspirational speech at a mass in the local church.

In the mass, Rosa and her sister were honoured by the mayor and thanked for their efforts, and she gave a speech. Later that day, everyone gathered in a big hall. The visiting group provided many roasted pigs (lechón) and other food for everyone in the village. After that, many homes in the village were open to anyone to drop in for food and, in some cases, live music. A money dance, where people danced and hurled paper money onto the dance floor while dancing, was held in the evening. The money was then collected into baskets by young people to be used for the renovation of the sports area of the village. The participants from Iceland were visible in the dance and displayed their generosity. Similar to Grace, Rosa and her sister have central roles in a group of Filipinos in Iceland based on mobilizing their capital within the Filipino community. Unlike Grace, Rosa continues to build social and economic capital in the Philippines and participates in life there by travelling frequently, contributing to her family, organizing collective remittances to her village and engaging life there on a regular basis. In a way, she is more concerned with her position there than in Icelandic society.

\section{Discussion and Conclusion}

This article examines the positions and experiences of women from the Philippines who have migrated to Iceland. By focusing on the migration trajectories of five women, it highlights their migrant capital and how they apply local and transnational social networks when finding a way to improve their lives in a new society. Their stories show some similarities in their experiences of being racialized and categorized as Asians in Iceland, but they also illustrate important differences within the group in terms of their abilities to utilize their capital and build new forms of capital. Bourdieu's theories of social, economic and cultural capital highlight the importance of the class and hierarchical relations that affect the women as a minority group in Iceland. The theories are also reflected in the different positions the women hold. Bourdieu's theoretical perspectives, in addition, draw attention to people's agency in changing their positions within a social structure while navigating a new society. A transnational perspective sheds light on how different positions prior to migration and continuing ties with the Philippines play roles in this process.

The stories of the five women show both similarities and differences in migration trajectories. They all talked repeatedly about their longing to make better lives for themselves and their families as the most important reasons for migration. They have also, in various ways, experienced prejudice at work or in Icelandic society. The women's stories depict important differences when it comes to their positions in Icelandic society and their abilities to mobilize migrant capital. It is clear from the women's stories that the social networks within which they mobilize their capital are not just based on nationality, but also to a varying degree on extended family ties and transnational connections within certain locations in the Philippines. Similar to Kelly and Lusis's (2006) study of Filipinos in Canada, the social networks of Filipinos in Iceland can be described as localizations of transnational ties with family and people from the same locality in the Philippines. Being from the Philippines may not, in and of itself, give access to such networks, as we saw with the two sisters left out of Grace's network (Paul, 2013).

Applying the Bourdieusian approach of social and cultural capital highlights how people do not start with the same resources in terms of social, economic or cultural capital because of the different class positions into which they are born. Three of the five women come from middle-class families in the Philippines, whereas Vanessa comes from a low-class family and Anna from a rather well-off family that emphasises cultural capital. These different class positions are reflected in, among other things, their educational backgrounds. Four of the five women have a college degree, and Elsa completed a master's degree after coming to Iceland. She and Anna have been able to apply their education in Iceland. Anna, in addition, has been able to transfer her cultural capital, in terms of her education and writing, to the Icelandic context. The other two, Rosa and Grace had both finished a college degree before emigrating from the Philippines but have not applied their education on the Icelandic labour market. Despite holding low-income jobs, Grace, being married to a man who has a good job, identifies with her role in the Filipino community of her town. Rosa claims that she did not really try hard to get her education evaluated. They have both been working in jobs typical for immigrant women, such as cleaning. Their experiences reflect the increasingly ethnically segregated work force in Iceland (Júlíusdóttir et al., 2013). As Kristjánsdóttir and Christiansen (2019) have pointed out, foreign born women are commonly overeducated. As visible minorities in Iceland, all five women been affected by racialization as Asians in Iceland, which is also evident in their labour market positions (Loftsdóttir, 2017; Skaptadóttir, 2015). Even Anna and Elsa, who have been able to work in their field of education, have been confronted with discriminatory practises at work.

From the stories of the five women, we can see the variety of ways in which the women apply their agency. Mobilizing migrant capital is not only about being able to utilize their education in the host society, as is evident in the cases of Grace and Rosa. Both have, instead, been able to activate social networks and build their cultural 
capital by raising their status among a group of Filipinos in Iceland. In addition, Grace's position is also recognised by the Icelanders in her town. Her powerful position is, to some extent, based on her knowledge of Icelandic society and from other people being dependent on her. Moreover, she is well off economically as her husband has a good job and is highly educated. Rosa's capital building connects with both the near and the far, as her respect in Iceland among Filipinos is also reflected in symbolic capital in her home town where she has been able to maintain her cultural and social capital and contribute economically to her individual family and to the community by organizing collective remittances. Although Grace and Rosa have extensive migrant capital, it is only somewhat extended to Icelandic society in the case of Grace and very little in the case of Rosa.

Anna, who comes from a family with a great deal of social and cultural capital in the Philippines, did not have strong intentions to move to another country but only migrated because of her mother's encouragement. She has not focused much on strengthening her position among Filipinos because her position is relatively secure, and she has a strong network of Filipinos in Iceland, although she does not have relatives in Iceland. Instead, she has emphasized maintaining the position of the family back in the Philippines and mobilizing her resources to build her capital in Icelandic society. The different possibilities between her and Vanessa, and to some extend the other three women, show the importance of considering migrant capital in terms of how class intersects with individual motivations or family networks.

Unlike Anna, Vanessa had very little capital on which she could build as she did not have an education or any Filipino family in Iceland when she arrived. For her, marriage to a foreign man was a way to migrate and to help her family in need. Not having any relatives in Iceland, she was able to seek help from women coming from the same locality in the Philippines. Elsa's middle-class family had invested in her education, but like Vanessa, she had no kin when she came to Iceland. She could build on the education she had acquired prior to migration to improve her position in the hotel sector. Since arriving in Iceland, she has capitalized on her education and on becoming part of Icelandic society, more or less ignoring the Filipino community and not teaching her children her mother tongue. Although not maintaining strong ties with people in the Philippines, she proudly contributes to the welfare of her close family there with regular remittances.

Through transnational ties, migrants are able to maintain and improve social capital (Kelly \& Lusis, 2006). As we can see, some of the women draw on the formal and informal resources available to them in Iceland and on their transnational social field, such as their extended kin groups in Iceland and networks in the Philippines, to build their social capital both in Iceland and in the Philippines. The study shows that the transnational social field can be important and that mobilizing capital can be part of strengthening an individual's position. For both Anna and Rosa, the transnational and local levels are very much interconnected, and their migrant capital cannot be understood from only examining either the Icelandic or the Filipino local level. However, their transnational connections are very different and reflect their different position in the Philippines, where Anna was born into a family with a lot of capital. The women's transnational practices and utilization of resources to build migrant capital takes place in the context of a Filipino national ideology that encourages people to leave in order to care for those left behind. Most of the participants in my study emphasised this as an important factor in their decision to migrate. At the same time, the structural context of racialization and class position in Iceland affects their positions. While having improved their positions based on stronger economic, and in some cases social and cultural, capital, they have also experienced prejudice as Asians in Iceland. The individual stories analysed in the article demonstrate how the women can mobilize their resources, but the degree to which they can do this varies because of structural features such as class and racialization intersecting and displaying heterogeneity and hierarchies among Filipinos and within Icelandic society.

\section{Acknowledgments}

This research was funded by the Icelandic Research Fund (grant number 090617023). The writing of the article was supported by the project of excellence Mobility and Transnational Iceland, funded by the Icelandic Research Fund (grant number 163350-051).

\section{Conflict of Interests}

The author declares no conflict of interests.

\section{References}

Alberti, G. (2014). Mobility strategies, 'mobility differentials' and 'transnational exits': The experiences of precarious migrants in London's hospitality jobs. Work, Employment and Society, 28(6), 856-881.

Anderson, B. (2010). Migration, immigration controls and the fashioning of precarious workers. Work, Employment and Society, 24(2), 300-317.

Anthias, F. (2007). Ethnic ties: Social capital and the question of mobilisability. The Sociological Review, 55(4), 788-805.

Barber, P. G. (2008). The ideal immigrant? Gendered class subjects in Philippine-Canada migration. Third World Quarterly, 29(7), 1265-1285.

Barber, P. G. (2010). Women's work unbound. Philippine development and global restructuring. In M. H. Marchand \& A. S. Runyan (Eds.), Gender and global restructuring: Sightings, sited and resistances (2nd ed., pp. 143-162). London: Routledge.

Bourdieu, P. (1986). The forms of capital. In J. G. Richard- 
son (Ed.), Handbook of theory and research for the sociology of education (pp. 241-258). New York, NY: Greenwood Press.

Bourdieu, P., \& Wacquant, L. J. D. (1992). An invitation to reflexive sociology. Chicago, IL: The University of Chicago Press.

Erel, U. (2010). Migration cultural capital: Bourdieu in migration studies. Sociology, 44(4), 642-660.

Erel, U. (2015). Thinking migrant capitals intersectionally: Using a biographical approach. In L. Ryan, U. Erel, \& A. D’Angelo (Eds.), Migrant capital: Networking, identities and strategies. Migration, diasporas and citizenship (pp. 18-32). Houndmills: Palgrave Macmillan.

Erel, U., \& Ryan, L. (2019). Migrant capitals: Proposing a multi-level spatio-temporal analytical framework. Sociology, 53(2), 246-263.

Glick Schiller, N. (2010). A global perspective on transnational migration: Theorizing migration without methodological nationalism. In R. Bauböck \& T. Faist (Eds.), Diaspora and transnationalism: Concepts, theories and methods (pp. 109-130). Amsterdam: Amsterdam University Press.

Júlíusdóttir, M., Skaptadóttir, U. D., \& Karlsdóttir, A. (2013). Mapping gendered migration in turbulent times in Iceland. Norwegian Journal of Geography, 67(5), 266-275.

Kelly, P., \& Lusis, T. (2006). Migration and the transnational habitus: Evidence from Canada and the Philippines. Environment and Planning A: Economy and Space, 38(5), 831-847.

Kristjánsdóttir, E. S., \& Christiansen, P. H. (2019). “Hana langar ekki að missa mig": Upplifun háskólamenntaðra innflytjenda frá Filippseyjum af samskiptum og ađlögun á íslenskum vinnumarkađi ["She does not want to lose me": The experiences of university educated immigrants from the Philippines of communication and integration in the Icelandic labor market]. Íslenska pjóđfélagið, 10(2), 48-62.

Loftsdóttir, K. (2017). Being 'the damned foreigner': Affective national sentiments and racialization of Lithuanians in Iceland. Nordic Journal of Migration Research, 7(2), 70-78.

Madianou, M., \& Miller, D. (2012). Migration and new media. Transnational families and polymedia. London: Routledge.

Mahler, S. J., \& Pessar, P. R. (2006). Gender matters. Ethnographers bring gender from the periphery toward the core of migration studies. International Migration Review, 40(1), 27-63.

McDowell, L. (2008). Thinking through work: Complex inequalities, constructing of difference and transnational migrants. Progress of Human Geography, 32(4), 491-507.
Parreñas, R. S. (2005). Long distance intimacy: Class, gender and intergenerational relations between mothers and children in Filipino transnational families. Global Network, 5(4), 317-336.

Paul, A. M. (2013). Good help is hard to find: The differentiated mobilization of migrant social capital among Filipino domestic workers. Journal of Ethnic and Migration Studies, 39(5), 719-739.

Paul, A. M. (2015). Capital and mobility in the stepwise international migrations of Filipino migrant domestic workers. Migration Studies, 3(3), 438-459.

Rahman, M. M., \& Lian, K. F. (2012). Towards a sociology of migrant remittances in Asia: Conceptual and methodological challenges. Journal of Ethnic and Migration Studies, 38(4), 689-706.

Ryan, L., Erel, U., \& D’Angelo, A. (2015). Introduction: Understanding 'migrant capital.' In L. Ryan, U. Erel, \& A. D’Angelo (Eds.), Migrant capital: Networking, identities and strategies. Migration, diasporas and citizenship. (pp. 3-17). Houndmills: Palgrave Macmillan.

Schrover, M., der Leun, J. V., \& Quispel, C. (2007). Niches, labour market segregation, ethnicity and gender. Journal of Ethnic and Migration Studies, 33(4), 529-540.

Skaptadóttir, U. D. (2015). Women and men on the move: From the Philippines to Iceland. In S. T. Faber \& H. P. Nielsen (Eds.), Remapping gender place and mobility: Global confluences and local particularities in Nordic peripheries (pp. 143-158). Aldershot: Ashgate.

Skaptadóttir, U. D., \& Garðarsdóttir, Ó. (in press). Becoming an immigration country: Demographic changes in Iceland in the beginning of the 21st century. In K. Loftsdóttir, U. D. Skaptadóttir, \& S. B. Hafsteinsson (Eds.), Mobility and transnational Iceland. Current transformations and global entanglements. Reykjavík: University of Iceland Press.

Spitzer, D., Neufeld, A., Harrison, M., Hughes, K., \& Stewart, M. (2003). Caregiving in transnational context: "My wings have been cut: Where can I fly?" Gender \& Society, 17(2), 267-285.

Standing, G. (2011). The precariat: The new dangerous class. London: Bloomsbury Academic.

Statistics Iceland. (n.d.). Population by country of birth, sex and age 1 January 1998-2018. Retrieved from https://px.hagstofa.is/pxen/pxweb/en/Ibuar/lbuar_ _mannfjoldi_3_bakgrunnur_Faedingarland/ MAN12103.px

Vertovec, S. (2006). Migrant transnationalism and modes of transformation. International Migrant Review, 38(3), 970-1001.

Yingst, A., \& Skaptadóttir, U. D. (2018). Gendered labor in the Icelandic fish processing industry. Maritime Studies, 17(2), 125-132. 


\section{About the Author}

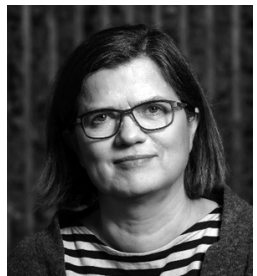

Unnur Dís Skaptadóttir is a Professor of Anthropology at the University of Iceland. Her research focuses on various aspects of international migration, such as transnationalism, labor migration, experiences of refugees and asylum seekers, national identity and language. She has recently published on these topics in Migration Studies, Refuge, Nordic Journal of Migration Research and Journal of Immigration \& Refugee Studies. She is currently a co-organizer of the Center of Excellence project Mobilities and Transnational Iceland. 